\title{
A Interpretação do Supremo Tribunal Federal para as Anistias Políticas Concedidas ao Longo do Período Republicano Brasileiro
}

\section{The Interpretation of the Supreme Court to Political Amnesties Granted in the Brazilian Republican Period}

\author{
Rosangela Souza Bernardo ${ }^{1}$ \\ Filomeno Moraes ${ }^{2}$ \\ ${ }^{1}$ Faculdade Princesa do Oeste, Crateús, CE, Brasil \\ ${ }^{2}$ Universidade de Fortaleza, Fortaleza, CE, Brasil
}

\begin{abstract}
Resumo: O presente estudo analisa as correlações existentes entre as condições da política nacional e a jurisprudência do Supremo Tribunal Federal que versa sobre anistia política. Neste artigo serão debatidos o militarismo e as características da política nacional como elementos conformadores da interpretação realizada pelo Supremo Tribunal Federal para as anistias políticas. A metodologia utilizada foi a investigação do tipo documental-bibliográfica, com pesquisa pura de abordagem qualitativa, descritiva e exploratória quanto aos objetivos. Conclui-se que fatores políticos interferem na interpretação das anistias políticas e que tal intervenção resulta da aproximação institucional construída entre os militares e os membros da cúpula do Poder Judiciário.
\end{abstract}

Palavras-chave: Anistia Política. Supremo Tribunal Federal. Militarismo.
Abstract: This study analyzes the existent correlations between the situation of national politics and the jurisprudence of Supreme Court that traverses on the political amnesty. It is debated the militarism and the characteristics of the national politics while elements that shape the interpretation made by the Supreme Court regarding political amnesties. The methodology used was documental-bibliographic investigation, with qualitative, descriptive and exploratory research regarding the objectives. The conclusion is that political factor interferes in the interpretation of political amnesties and that such intervention results from the institutional approximation built between military and the members of the Judicial Power.

Keywords: Political Amnesty. Supreme Federal Court. Militarism.

Recebido em: 04/12/2018

Revisado em: 18/02/2019

Aprovado em: 28/02/2019 


\section{Introdução}

As anistias políticas são medidas jurídicas comumente utilizadas na política nacional como instrumentos de gestão do poder. Sua destinação precípua, que é promover o esquecimento de crimes quanto a seus efeitos penais e processuais penais, convive com as marcas da política nacional que podem ser sintetizadas como o continuísmo político, a conciliação e o abandono dos instrumentos democráticos de governo. A partir dessas características, o recurso ao emprego das forças de segurança do Estado mostra-se, por vezes, apropriado.

A anistia política pode ser concedida em benefício de grupos civis ou militares. Quando alcança grupos militares, a anistia pode alcançar distintas ações, desde atos de insubordinação a crimes comuns praticados contra a oposição ao governo. Neste último caso, a anistia produzida representa uma das prerrogativas das instituições militares que atuam como garantidores da lei e da ordem constitucional. No presente, os militares lutam para resguardar as condições estabelecidas na Lei n. 6.683, de 28 de agosto de 1979, e afastar as atitudes que possam representar aquilo que denominam "revanchismo".

Diversos atos normativos de anistia concederam benefícios a grupos militares. A vigência da Lei n. 6.683 impede a persecução penal para apurar os crimes cometidos no curso da ditadura militar. E, embora os dispositivos constitucionais prevejam o repúdio ao crime de tortura e o Estado brasileiro tenha sofrido condenação perante a Corte Interamericana de Direitos Humanos (CIDH) em razão dos casos de violações de direitos que aconteceram na região do Araguaia, o sistema de justiça reconhece a validade da anistia concedida como parte do acordo de transição traçado entre o governo militar e as elites nacionais.

A conjuntura política vivenciada pelo Poder Judiciário na atualidade expressou a necessidade de continuar cumprindo o acordo firmado para que a transição política garantisse a entrega do governo aos civis. A postura do Supremo Tribunal Federal (STF) ao julgar a Arguição de Descumprimento de Preceito Fundamental (ADPF) n. 153, adotando argumentos jurídicos e sociológicos, ratificou o discurso da estabilidade 
política no presente. Igualmente, a Justiça Federal vê-se às voltas com diversas ações penais promovidas pelo Ministério Público Federal para apurar crimes cometidos pelos militares, como forma de cumprimento da decisão da CIDH, e reconheceu a validade da Lei de Anistia de 1979.

Ademais, o Supremo está diante do desafio de julgar a ADPF n. 320, impetrada com o propósito de forçar o cumprimento da determinação da CIDH pelo Estado brasileiro. Todas essas considerações levam a questionar o papel do Poder Judiciário nacional para a consolidação da democracia, especialmente quanto à interpretação dos atos normativos concessivos de anistia política.

Analisar a jurisprudência produzida pelo Supremo Tribunal Federal sobre as anistias políticas permite discutir a postura tomada pelo Poder Judiciário estabelecendo relações com a cultura política nacional e com as exigências firmadas pela ordem democrática inaugurada em 1988. O objetivo da presente pesquisa é analisar as relações entre a interpretação que o Supremo realiza para os atos concessivos de anistia política e as condições da política nacional, considerando, especialmente, o processo de transição política experimentado a partir da década de 1970 e as características da nova ordem constitucional.

A pesquisa orientou-se a partir do questionamento em torno do papel desempenhado pelo Poder Judiciário ao interpretar os atos normativos de anistia política e ao gerenciar a criminalidade política. Ademais, indaga sobre o papel dos militares na vida política nacional, as suas relações com os Poderes do Estado, os princípios que regem a sua atuação e o seu peso como instituição que, comumente, se beneficiou das anistias políticas produzidas durante o período republicano brasileiro. A perspectiva adotada tornou complexo o ato de anistia política destinado aos militares, uma vez que considerou os aspectos relevantes para as instituições castrenses e a sua participação na construção de relações de poder.

A pesquisa é descritivo-analítica e volta-se para descrever e compreender as relações existentes entre a interpretação dos atos normativos que concedem anistia política e a política nacional. Ademais, é exploratória, pois busca aprimorar as ideias sobre o tema. Quanto aos resultados obtidos, a pesquisa buscou compreender a problemática exposta, bem 
como suscitar as razões para os problemas identificados. Trata-se, ademais, de pesquisa pura, pois tem como objetivo à ampliação dos conhecimentos, e qualitativa, vez que busca apreciar a abordagem atual sobre o tema no ordenamento jurídico pátrio. Para tanto, utilizou-se de pesquisa documental junto ao acervo de jurisprudência do Supremo Tribunal Federal, por meio do serviço de pesquisa de jurisprudência disponível no sítio eletrônico da instituição, e de pesquisa bibliográfica realizada em livros e artigos de periódicos que abordam direta ou indiretamente o tema.

A pesquisa, inicialmente, discute os elementos conformadores da política nacional, buscando elucidar as principais relações de poder que influenciam a interpretação dos atos normativos concessivos de anistia política. Em seguida, é analisado o conjunto de decisões proferidas pelo Supremo Tribunal Federal identificado, debatendo-se aspectos fixados nas decisões que são capazes de orientar as principais questões suscitadas pela aplicação da Lei de Anistia n. 6.683, de 1979, hodiernamente. Por fim, pondera-se acerca das condições políticas e dos grupos de poder que instigam o Supremo ao interpretar as anistias políticas sob a égide da Constituição Federal de 1988.

\section{A Política Nacional, o Papel das Anistias Políticas e as Rela- ções de Poder}

O Supremo Tribunal Federal processa duas ações de controle concentrado de constitucionalidade que discutem aspectos da aplicação da Lei de Anistia n. 6.683, de 1979. São as Arguições de Descumprimento de Preceito Fundamental de n. 153 e de n. 320. A primeira delas questiona a recepção pela ordem constitucional de 1988 da referida lei, especialmente questionando a amplitude da conexão criminal adotada pela legislação. A segunda, por sua vez, pede que o Estado brasileiro cumpra, integralmente, a decisão proferida pela Corte Interamericana de Direitos Humanos no caso Gomes Lund e declare que a Lei de Anistia referida não se aplica a graves violações de direitos humanos.

A decisão da segunda demanda, ajuizada em 2014, pode interferir no resultado prático do julgamento proferido na ADPF n. 153, de 2010, 
que reconheceu a recepção da referida anistia pela ordem constitucional em vigor. As anistias políticas veem sendo concedidas pelo Estado brasileiro ao longo de sua história republicana e integram o rol de mecanismos que compõem o exercício do jogo do poder político.

A perspectiva adotada pelo Estado ao produzir tais atos normativos, e ao interpretá-los, desenvolve-se em paralelo às regras de ouro da política nacional. Esta é construída a partir das regras da conciliação entre os interesses dos grupos de maior influência política; do continuísmo de maneirismos e de atores, independentemente do regime adotado; do uso dos instrumentos democráticos para viabilizar os objetivos acordados; do usual desprezo às regras políticas adotadas e do recurso ao uso das forças de segurança do Estado como meio para forçar o cumprimento dos propósitos traçados. As anistias políticas resultam, portanto, de decisões construídas no curso do processo político desenvolvido segundo os critérios acima elencados.

As anistias políticas podem ser concedidas em benefício de militares que cometem crimes para resguardar a ordem política e a lei, nesse caso, tais medidas passam a integrar o quadro das prerrogativas militares. Estas são formadas por um conjunto de medidas, garantias legais e atitudes políticas voltadas para fortalecer a sua destinação institucional. Em última instância, conclui-se que as anistias políticas assim concedidas favorecem a manutenção do papel tradicionalmente conferido às Forças Armadas e, indiretamente, beneficiam os agentes castrenses responsáveis diretos pelas operações.

O autoritarismo e a democracia no Brasil república mesclam-se e desenvolvem-se imbrincados. A composição do poder é resultado do contato entre grupos estratégicos do governo e as elites civis. Dessa união, resulta forte tendência para excluir os grupos populares. A democracia, portanto, é alicerçada a partir de tais estruturas de poder e resta sempre ameaçada quando as forças políticas não logram a composição conforme o desiderato dos grupos de maior expressão política, através dos canais institucionais existentes. Em tal contexto, o uso das forças de repressão estatal mostra-se, por vezes, o recurso adequado para tratar questões políticas. 
Entre os grupos estratégicos que integram o Estado e que disputam o exercício do poder encontra-se o corpo militar. O poder militar realiza-se, como influência política, construindo alianças e definindo o tipo de atuação cabível a partir do contato direto com outros grupos. A aproximação entre militares e os demais grupos pode acontecer de diversas formas, desde reuniões informais (SERBIN, 2001, p. 204), almoços institucionais (STEPAN, 1975, p. 72-73), até a troca de experiências ao desenvolver trabalhos em parceria com demais integrantes do ente estatal (PEREIRA, 2010, p. 284). A estratégia depende, basicamente, das circunstâncias e do nível de tensões.

O autoritarismo experimentado a partir de 1964 representa o ponto culminante do desenvolvimento das Forças Armadas, como instituição nacional, projeto gestado desde a década de 1920, e o aprofundamento dos laços consensuais firmados com o Poder Judiciário nacional. As vítimas da repressão política foram beneficiadas pelos consensos construídos entre as duas instituições uma vez que a judicialização evitou a ruptura total com os procedimentos legais. No entanto, o sistema judicial se alterou e tomou uma direção conservadora que subsistiu para além da experiência ditatorial (PEREIRA, 2010, p 288 e 294), e, sob a égide da Constituição Federal de 1988, não pode ser concretizada a punição de agentes do Estado que cometeram graves violações.

Assim, pode-se concluir que os limites institucionais determinam a forma tomada pela legalidade tanto em regimes autoritários como nos democráticos, onde igualmente verifica-se a tendência para promover alterações nas estruturas institucionais a fim de enfrentar emergências políticas. A jurisprudência produzida com base no fluxo da política indica a presença de fatores de politização do direito; o comprometimento em manter as instituições do Estado de Direito, embora não haja respeito aos contornos constitucionais dessas instituições; e, por fỉm, consolida as alterações dos princípios que orientam as instituições democráticas.

As análises a respeito do fim da influência militar com o advento do regime democrático são controvertidas. Algo é indiscutível, os militares permaneceram com algumas prerrogativas, no entanto, não há um consenso sobre o grau de interferência dos militares para a vida políti- 
ca. Medidas de transição compõem o acervo institucional do Estado para contornar dificuldades políticas oriundas das negociações para alterar o poder. Entre elas, inclui-se a inserção e a readequação das Forças Armadas na nova ordem (ZAVERUCHA, 2000; D’ARAÚJO, 2001).

Outro fator a ser considerado diz respeito à adequação do Poder Judiciário ao ideário fixado pela ordem democrática anunciada na Constituição Federal de 1988. Pode-se afirmar que as democracias inauguradas logo após regimes autoritários não conseguem se esquivar completamente das influências da legalidade e da mentalidade criada para fundamento do regime autoritário precedente (PEREIRA, 2010, p. 289). No caso brasileiro, o consenso entre as elites militares e judiciárias foi urdido bem antes do regime ditatorial de 1964.

O Tribunal de Segurança Nacional, sob os auspícios da Constituição de 1937, exercendo função de "justiça de defesa do Estado", agora sem a limitação do diploma legal que o instituiu, isto é, sem que fosse necessário declarar o estado de guerra, era composto por magistrados oriundos dos quadros militares e civis (NUNES, 1943, p. 437-438). A composição do Tribunal permitiu o contato entre os membros das instituições militares e judiciárias e a partilha de ideias de reciprocidade entre elas.

A legislação que orquestrou o Tribunal de Segurança Nacional impôs as maiores restrições ao direito de defesa e, ademais, o "julgamento por livre convicção", nos casos de crimes contra a existência, segurança e integridade do Estado e contra a estrutura das instituições, indica o nível de controle pretendido. Os membros do Tribunal estavam encarregados de zelar pelo cumprimento dessa legalidade, cujo fundamento encontrava-se no ideário da luta contra o avanço comunista no país. Os entendimentos a serem adotados para o funcionamento dos trabalhos do órgão e as medidas aplicáveis aos casos foram o resultado do consenso construído entre seus membros a partir de tais referências.

As transições políticas verificadas no Estado brasileiro envolveram medidas de continuísmo, com base na cooperação entre as elites civis e os integrantes do governo, por vezes, contando com o apoio militar direto. A colaboração entre os militares e o Poder Judiciário aconteceu quando os militares estiveram no poder ou, simplesmente, quando eles integraram 
órgãos do Poder Judiciário. O arranjo institucional para aplicar a justiça penal, de um modo geral, trata a violência praticada pelas instituições de segurança do Estado e aquela praticada pelos dissidentes políticos diferentemente. Quanto à interpretação das anistias políticas produzidas, a responsabilidade do governo não é discutida e a exegese tende a tratar ambos os grupos com reciprocidade.

O Estado brasileiro adota leis de anistia como mecanismo para enfrentar o legado da violência provocada, indistintamente, pelas ações dos dissidentes políticos e aquelas praticadas pelas instituições de segurança. A Lei n 6.683, de 1979, destaca-se nesse cenário por ser reflexo do momento autoritário de maior expressão vivenciado no Brasil, devido ao aprimoramento institucional da repressão promovida, e por repercutir na vida política durante o período regido pela Constituição de 1988.

Debate-se a compatibilidade dessa anistia com a ordem constitucional de 1988 e as condições jurídicas e políticas de aplicação de medidas de justiça de transição para apurar os crimes cometidos pelos agentes do Estado encarregados da repressão. A discussão sobre a reabilitação dos militares para a experiência democrática questiona, necessariamente, o papel da justiça de transição e a interpretação dada a Lei de Anistia de 1979. Por certo, a decisão sobre aplicar a justiça de transição não é consensual, tanto por razões políticas como por razões jurídicas.

\section{O Supremo Tribunal Federal e sua Interpretação das Anistias Políticas}

O conjunto de decisões do Supremo Tribunal Federal que será analisado a seguir aborda aspectos relevantes para o estudo das anistias políticas, especialmente ligados aos temas da conexidade; ao alcance da interpretação dos atos de anistia; a responsabilidade para revê-los; às diferenças interpretativas entre os efeitos civis e os penais decorrentes de tais atos e ao tratamento oferecido aos sujeitos beneficiados por essas medidas. 
Quanto ao tópico da conexão criminal, na decisão do Habeas Corpus n. 1.386, de 4 de julho de 1900, o Supremo Tribunal Federal decidiu que, havendo continuidade delitiva, trata-se de caso de conexidade, isto é, de um só crime com resultados diversos (BRASIL, 1900, p. 83). A motivação política das ações criminosas empreendidas pelos pacientes do caso concreto em apreciação, o assassinato de duas pessoas e o assalto e o controle de estação telegráfica, justificou a incidência da Lei n. 310, de 21 de outubro de 1895, que concedeu anistia aos participantes dos movimentos armados conhecidos como "Revolução Federalista" e a "Revolta da Armada" (BRASIL, 1974, p. 8749) em razão do reconhecimento da conexão.

Desenvolvendo semelhante raciocínio, ao decidir o Recurso de Habeas Corpus n. 28.294, de 14 de outubro de 1942, impetrado para ver cessar processo criminal que tramitava contra um capitão reformado da Polícia do Estado de Pernambuco e dois ex-soldados, da mesma corporação, como coautores de homicídio doloso praticado contra três integrantes da "coluna revolucionária" levantada em 1926, o Supremo Tribunal Federal reconheceu a aplicação do Decreto n. 19.395, de 8 de novembro de 1930, ao caso, uma vez que os crimes conexos aos crimes políticos e militares foram, expressamente, abrangidos por esta medida. Afirmou, ainda, que as anistias não podem ser interpretadas com cortes e interpolações devido seu alcance político (BRASIL, 1942, p. 11).

Ainda quanto ao tema da conexidade, o julgamento do Habeas Corpus n. 59.834, de 4 de maio de 1982, fomentou discussões que giraram em torno da conexão especial tecida pela Lei n. 6.683, de 28 de agosto de 1979, relacionando os crimes políticos praticados e, ainda, os crimes cometidos por motivação política, com outros que ostentem qualquer natureza. $\mathrm{O}$ voto do Ministro Décio Miranda condensou as ideias principais da celeuma jurídica que vinham sendo traçada nos votos anteriormente oferecidos.

Para esse Ministro, a Lei de Anistia debatida não adotou um conceito rigoroso de conexão, deixando de seguir a doutrina penalista. $\mathrm{O}$ artigo primeiro da lei trouxe expressa referência a anistia de crimes políticos e os conexos. O legislador, ademais, achou por bem definir a conexão a ser 
aplicada e relacionou crimes políticos e crimes praticados por motivação política com outros de qualquer natureza. Concluiu o Ministro que o conceito de conexão adotado por essa anistia foi mais amplo, o que permitiu relacionar o crime militar de deserção em conexão com os crimes perpetrados pelo mesmo agente contra a segurança nacional, dos quais fora anistiado (BRASIL, 1982, p. 213-214).

Observa-se que o agente criminoso, o qual buscava o amparo do remédio constitucional em exame, era castrense e insatisfeito com o regime militar. A deserção foi considerada meio para a prática de outros crimes, desta feita, ofensas contra a segurança nacional. Nesse caso concreto, o reconhecimento de conexão especial prevista na Lei n. 6.683 beneficiou um militar cujas convicções eram contrárias ao regime. A interpretação ampliada da conexão não representou defesa irrefletida dirigida aos militares. Significou, sim, a aplicação da teoria penal relacionada à natureza da anistia política como expressão da orientação conciliatória presente na decisão.

Em regra, os crimes políticos anistiados contemplam os crimes conexos de forma natural, uma vez que, dessa maneira, resulta ampliado o oblívio penal. Ao legislador compete a tarefa de restringir o alcance da conexão, quando o caso recomendar, sendo corriqueira tal medida; ou, então, fixar-lhe seu alcance de modo mais amplo, sendo incomum esse uso. O parágrafo primeiro do artigo $1^{\circ}$ da Lei n. 6.683, de 1979, é exemplo de conexão especial no direito brasileiro por ampliar sobremaneira o sentido da conexão criminal. O caso não destoa da doutrina uma vez que o conceito especial foi explicitamente traçado.

A seguir, será analisada a percepção do Supremo Tribunal Federal acerca dos parâmetros interpretativos aplicáveis às leis de anistia política. A visão fixada pela cúpula do Poder Judiciário nacional estabelece os pilares para a interpretação de tais tipos normativos por outros membros do Poder; explicita o papel do Poder Judiciário e do Poder Legislativo quanto ao tema da revisão das anistias e define os critérios para a realização de interpretação ampla ou restrita, a depender dos tipos de consequências pleiteadas em juízo. 
Em síntese, as decisões afirmam que a interpretação das leis de anistia deve dialogar com o momento histórico de sua produção; ao Poder Judiciário é vedado realizar a revisão desses atos normativos, cabendo a tarefa ao Poder Legislativo; a interpretação deve ser ampla quando a análise versar sobre o oblívio penal; por outro lado, a interpretação deverá ser restrita, quando discutir as consequências civis ou administrativas de tais atos e, por fim, fixou-se a tese de que eventuais limitações dos benefícios penais devem ser definidas, exclusivamente, pelo Poder Legislativo.

Primeiramente, o Ministro Orosimbo Nonato, no seu voto no Habeas Corpus n. 29.151, de 26 de setembro de 1945, defendeu a tese de que cabe ao aplicador da lei que concede o benefício verificar a finalidade do mesmo, atendendo ao momento histórico em que ela surgiu e ao escopo a que visa, sem se deixar agrilhoar à literalidade do texto normativo por puro rigor técnico (BRASIL, 1945, p. 210).

O mesmo Ministro, no Recurso Extraordinário Criminal n. 10.177, de 11 de maio de 1948, ao discutir o cabimento do Decreto-Lei n. 7.943, de 10 de setembro de 1945, ao caso, sustentou a concepção de que ao Poder Judiciário apenas compete o encargo de interpretar a lei que traduz a anistia, sua extensão e alcance quanto aos fatos e às pessoas. Conclui, portanto, que a estrutura do poder competente para alterar uma dada Lei de Anistia é o Poder Legislativo (BRASIL, 1948, p. 223).

Na mesma toada, o Ministro Relator do Recurso Extraordinário Criminal n. 10.998, de 7 de junho de 1948, Barros Barreto, ao decidir sobre a aplicação do mesmo Decreto-Lei n. 7.943 a outro caso, defendeu semelhante tese quanto à impossibilidade de revisão de uma Lei de Anistia pelo Poder Judiciário, desta feita, discutindo a interpretação realizada pelo magistrado de primeiro grau, que foi contrária ao texto expresso do Decreto, o qual estendeu a anistia aos crimes comuns praticados durante as manifestações coletivas, ocasionando a necessidade de interposição de recurso perante o Supremo (BRASIL, 1948, p. 168-169).

A conclusão a que chegou o Supremo Tribunal Federal é que a disposição legal expressa de anistiar os crimes de qualquer natureza ocorridos nos entremeios das manifestações públicas, sobre as quais incidem os benefícios penais, impõe ao Poder Judiciário o dever de aplicá-la ao 
caso concreto e beneficiar o agente criminoso, evidenciando a concepção de que a decisão sobre anistiar esse ou aquele crime compete ao Poder Legislativo.

Em outro julgado, de 1991, no Recurso Extraordinário n. 125.641, seguindo o voto do Ministro Relator Celso de Mello, a mesma questão apresenta-se de maneira diferente. $\mathrm{O}$ caso tratou da aplicação da anistia prevista no artigo $4^{\circ}$ da Emenda Constitucional n. 26, de 1985, para militares excluídos da Força Aérea Brasileira em razão de infrações disciplinares punidas com base na legislação militar ordinária, conflitando com o dispositivo expresso da Emenda, que previu a anistia apenas para os militares afastados em razão de atos de exceção, institucionais ou complementares.

A análise da matéria versou sobre as consequências de natureza administrativa da anistia assegurada. Para o Supremo, apenas os efeitos penais das anistias devem ser interpretados de maneira ampla; as consequências cíveis ou administrativas devem ser interpretadas restritivamente, uma vez que são elementos acidentais para esse tipo de norma. A interpretação extensiva, caso concretizada no julgamento, representaria uma alteração na norma por via judiciária, o que se mostra inapropriado, uma vez que compete ao Congresso Nacional a revisão de tais atos (BRASIL, 1991, p. 580-581).

O julgamento do Habeas Corpus n. 34.866, de 03 de abril de 1957, no voto do Ministro Relator Luiz Galati, explicita o pensamento que conforma o modo de interpretação das consequências penais das leis de anistia política no Brasil. O caso discutiu a possibilidade da aplicação do Decreto n. 27, de 20 de junho de 1956, aos instigadores de movimentos grevistas. A anistia concedida através deste decreto dirigiu-se aos trabalhadores que, por motivos relacionados ou decorrentes da participação em movimento grevista ou em disputas de direitos assegurados em legislação social, encontravam-se acusados ou condenados por determinados crimes indicados na norma; ademais, excluiu, expressamente, o homicídio doloso, ainda que praticado durante ou em consequência dos atos grevistas. O Supremo Tribunal Federal compreendeu que as pessoas que incitaram movimentos grevistas, embora não tenham efetivamente participado 
deles, são beneficiadas pelo referido Decreto, uma vez que a clemência excluiu apenas o crime de homicídio doloso.

Como o oblívio destina-se a atingir crimes, a interpretação para alcançar delitos deverá ser ampla. Caso o legislador deseje restringir o alcance criminal do instituto, deverá fazê-lo explicitamente. Vale recordar que somente ao Poder Legislativo compete tal mister. No caso em análise, a lei excluiu apenas o homicídio doloso, o que levou o Supremo a incluir as condutas de instigar, preparar, dirigir ou ajudar a greve na cobertura da anistia (BRASIL, 1957, p. 304-305).

O Recurso Criminal n. 1.019, de 5 de agosto de 1957, a partir do voto do Ministro Relator Ary Franco, debateu a possibilidade de ampliar a extensão penal do benefício de anistia numa outra perspectiva prática. No caso sob julgamento, os recorridos haviam redigido e publicado 12 números de boletins considerados subversivos, dois deles com data posterior à data fixada pelo Decreto Legislativo n. 22, de 23 de maio de 1956, para cobrir os atos anistiados, a saber, entre 10 de novembro de 1955 e $1^{\circ}$ de março de 1956.

Entretanto, os dois números do boletim foram distribuídos antes da publicação da referida Lei de Anistia. O Supremo entendeu que o objetivo do legislador foi o de abranger todos aqueles que houvessem praticado atos relacionados aos movimentos ocorridos a partir de 10 de novembro de 1955 voltados para garantir a posse dos candidatos eleitos para os cargos de Presidente e Vice-Presidente da República, Juscelino Kubitschek e João Goulart, respectivamente, e a resistência correlata à posse de tais personalidades, a qual restou conhecida como revolta de Jacareacanga (BRASIL, 1974, p. 8751).

Assim, o Supremo Tribunal Federal ampliou a data legal de referência para abarcar os fatos anistiados, fixou o limite na data da publicação do ato normativo que criou o benefício e garantiu o oblívio penal a um maior número de casos, todos pertinentes aos eventos ensejadores de tal medida (BRASIL, 1957, p. 245). Conclui-se que, para garantir maior proteção penal aos recorridos, o Supremo realizou interpretação ampla da anistia concedida, sem alterar a substância da decisão legislativa. 
Existe, ainda, outro aspecto da interpretação ampla conferida às leis de anistia. O voto do Ministro Relator Hahnemann Guimarães no Recurso Criminal n. 1.025, de 28 de abril de 1958, explicitou a questão ao analisar a anistia concedida a jornalistas pelo Decreto Legislativo n. 27, de 20 de junho de 1956. Esse texto normativo anistiou, entre outras pessoas, os jornalistas processados ou condenados por delitos de imprensa, não fixando qualquer data para considerar os fatos anistiados.

Nesse caso, o Supremo Tribunal Federal considerou que os jornalistas, no exercício de suas funções de imprensa, foram anistiados de maneira ampla pelo legislador, que deixou de estabelecer qualquer limite temporal (BRASIL, 1958, p. 21). Diferentemente do Decreto Legislativo n. 15, de 11 de junho de 1963, que concede anistia aos jornalistas e demais incursos em delitos de imprensa, por atos praticados no período compreendido entre a data da promulgação da Emenda Constitucional $\mathrm{n}$. 4, de 2 de setembro de 1961, que trata o sistema parlamentar de governo, e da de n. 6, que a revogou em 23 de janeiro de 1963.

Conclui-se que, uma vez estabelecido algum limite pelo legislador, tal assertiva deverá orientar o intérprete. Caso não tenham sido fixadas delimitações, ao julgador não cabe fazê-lo. Portanto, diante da ausência de restrições legais, a interpretação deverá ampliar, ao máximo, o benefício penal assegurado pela legislação. Essa é a orientação predominante nos julgados do Supremo Tribunal Federal, conforme se verifica da análise do universo apresentado. Quanto às consequências civis ou administrativas das anistias, essas deverão ser interpretadas restritivamente, uma vez que representam exceção ao instituto.

Pode-se, ainda, citar o Recurso Criminal n. 1.396, de 28 de setembro de 1979, para ilustrar a ampla interpretação conferida pelo Supremo ao instituto da anistia quanto às consequências penais. No caso em questão, discutiu-se a aplicação da Lei n. 6.683, de 28 de agosto de 1979, aos agentes que cometeram crimes contra a segurança nacional cujos processos não haviam alcançado o trânsito em julgado ao tempo da promulgação da referida lei.

A anistia de 1979 tratou diferentemente duas situações envolvendo o trânsito em julgado de decisões criminais condenatórias. Uma de- 
las refere-se aos agentes excluídos da anistia, a saber, os condenados por terrorismo, assalto, sequestro e atentado pessoal; enquanto a outra refere-se aos condenados por crimes alcançados pelo benefício. No primeiro caso, o Supremo compreendeu que é preciso condenação com trânsito em julgado, uma vez que resulta em exclusão da anistia; enquanto na segunda situação, que foi o objeto do recurso criminal em análise, não se exige para incluir no oblívio que a condenação tenha transitado em julgado, bastando que haja processo criminal instaurado contra os infratores (BRASIL, 1979c, p. 109).

Semelhante caso foi decidido no Recurso Criminal n. 1.401, de 21 de setembro de 1979, aplicando-se idêntico entendimento (BRASIL, 1979 b, p. 126 e 131). No Recurso Criminal n. 1.400, de 14 de setembro de 1979, debate-se a extensão da expressão "condenados" quando a Lei n. 6.683 exclui certos crimes de sua incidência. Considerou-se que a expressão "condenados", para excluir da anistia, exige o trânsito em julgado, confirmando a posição anteriormente esboçada (BRASIL, 1979a, p. 84 e 91).

Já o Recurso Criminal n. 1.410, de 5 de outubro de 1979, tratou de ambas as situações, conjuntamente, pois os recorrentes viviam circunstâncias delitivas distintas. Alguns deles puderam se beneficiar da anistia, uma vez que as infrações cometidas foram contra a segurança nacional, enquanto um deles, acusado por crime de assalto seguido de sequestro, com resultado morte, e condenado definitivamente, desistiu do recurso interposto, tendo sido homologado o seu pedido, uma vez que não era viável incidir a anistia sobre tal crime, naquele momento (BRASIL, 1979d, p. 329).

A construção jurisprudencial apresentada acima esboça o posicionamento do Supremo Tribunal Federal sobre os limites interpretativos aplicáveis às anistias políticas. Em síntese, os efeitos penais benéficos devem ser interpretados de maneira ampliativa. Assim, ao legislador compete indicar, expressamente, os limites dos efeitos penais de cada anistia política concedida. Se não o fizer, ao Poder Judiciário não é possível limitar os efeitos penais da medida. 
Nos julgados do Supremo Tribunal Federal analisados na presente pesquisa verificou-se diversas construções que permitiram a ampliação dos efeitos penais das medidas de anistias questionadas em juízo, entre elas, cita-se a variação do alcance temporal da norma, a inclusão de tipos penais compatíveis com a limitação descrita no texto legal e o tratamento diferenciado quanto à exigência do trânsito em julgado de decisão condenatória. A interpretação parte da realidade normativa para garantir a ampliação dos benefícios penais decorrentes da anistia política concedida. Por outro lado, quanto aos efeitos civis, a interpretação deverá ser restritiva, obedecendo aos parâmetros fixados no texto normativo.

Outro aspecto que chama a atenção e que conforma o quadro jurídico, político e cultural pertinente ao universo das anistias brasileiras é quanto ao tratamento dado aos sujeitos beneficiados pela interpretação realizada no seio do Poder Judiciário. Nem todos os acórdãos analisados acima identificam claramente as pessoas ou sua condição política. Mesmo assim, do exposto, percebe-se um quadro relevante construído pela jurisprudência do Supremo Tribunal Federal sobre aspectos elementares ligados à proteção conferida aos indivíduos beneficiados por tais medidas.

Os casos que identificaram as pessoas anistiadas, revelando, pelo menos, sua condição social ou política diante do regime, envolvem militares e policiais militares que praticaram crimes considerados sórdidos; militares excluídos da Força Aérea por infração disciplinar; trabalhadores de empresas estatais e privadas punidos por atos de greve; civis panfletários e jornalistas em atos de imprensa e em atos delitivos diversos.

Todos esses agentes receberam semelhante tratamento perante o $\mathrm{Su}-$ premo Tribunal Federal. Em linhas gerais, pode-se dizer que os agentes militares e os civis que cometeram crimes foram beneficiados por uma interpretação ampliativa do oblívio penal, independentemente da gravidade do ato, salvo limite expresso no texto de lei; por outro lado, as consequências civis são interpretadas restritivamente, não sendo relevante o grupo a que pertençam os sujeitos, se militares ou se civis.

Essa fórmula indica a coerência da jurisprudência brasileira com os ditames debatidos pela doutrina nacional para o instituto da anistia política. 
O Supremo Tribunal Federal atua de modo coerente e dialogal com a doutrina penalista, reduto primeiro do instituto da anistia. $\mathrm{O}$ estudo não revelou a existência de tratamento diferenciado entre os sujeitos, militares ou civis, que aportam suas demandas ao Poder Judiciário. A diferença interpretativa encontrada refere-se aos efeitos das anistias, não aos sujeitos que figuram nas demandas.

A análise da interpretação realizada pelo Supremo Tribunal Federal acima exposta permite concluir que, ao longo da história republicana brasileira, os aspectos relevantes da produção normativa dos atos de anistia política foram interpretados de forma uníssona, independentemente do momento político da produção normativa, se ditatorial ou democrático, vivenciado no país. Tal produção é resultado da visão conciliatória inerente à política nacional refletida no trabalho dos órgãos de cúpula do governo. A construção de consensos e do continuísmo presente na historiografia política nacional mostra sua influência marcante sobre o Poder Judiciário, especialmente nos momentos da queda dos meios democráticos de governo. $\mathrm{O}$ estudo da interpretação dos atos normativos concessivos de anistia política pelo Supremo igualmente revela a influência de tais características.

\section{A Interpretação do Supremo Tribunal Federal para as Anis- tias Políticas Durante a Vigência da Constituição Federal de 1988}

A Lei n. 6.683, de 1979, permanece gerando debates após a promulgação da Constituição de 1988 por promover a anistia de militares que cometeram graves crimes. O processo de transição política entre o regime militar e o compromisso democrático assumido pela nova ordem constitucional foi talhado estando os militares no comando e ditando as regras de transição. Ademais, a mobilização popular reivindicando eleições diretas e a anistia dos dissidentes políticos serviu como justificativa para a concessão de anistia também aos militares, como tradicionalmente operou o legislativo nacional. 
Observa-se que a conciliação que inspira a cooperação entre os militares e as elites, assim como cria liames entre os militares e os membros do Poder Judiciário, não deixou de ser pedra angular no processo de abertura. Tais marcas não puderam ser abandonadas nem mesmo diante do avançar da construção da nova ordem constitucional. Até o presente, para os militares, o "revanchismo" é repudiado como desprestígio para a instituição. Assim, a punição dos agentes militares que integraram os setores de segurança enfrenta renovados obstáculos.

Ademais, nota-se que as discussões doutrinárias sobre a construção da justiça de transição adotam, em regra, os parâmetros fixados no cenário internacional, cuja inspiração maior reside nas experiências dos julgamentos que se seguiram após o final da segunda guerra mundial na Europa Ocidental e a transição política construída na África do Sul, após o fim do regime de apartheid (MÉNDEZ, 2011, p. 223). As condições políticas, a realidade do ordenamento jurídico interno e as conquistas democráticas jurídico-institucionais realizadas pouco são levadas em consideração nas análises da construção da justiça de transição após o fim da ditadura de 1964.

Quanto à particular questão suscitada sobre a realidade local, a Lei n. 6.683 foi objeto de análise perante o STF que debateu o tema da recepção da referida lei pela nova ordem constitucional na ADPF n. 153. A decisão adotada ratifica as tendências construídas ao longo do processo de abertura política, utilizando-se, como apoio, de farta jurisprudência do próprio Supremo sobre o tema, que conforma uma certa visão de anistia política traçada desde o início do século XX e que se adequa à configuração da democracia atual.

A principal consequência do posicionamento adotado pelo Supremo Tribunal Federal na ADPF n. 153 é oferecer justificativa para a paralização das ações penais que tramitam na Justiça Federal com o objetivo de processar e punir agentes militares envolvidos nos crimes cometidos em meio à repressão aos dissidentes políticos do regime de 1964. São 27 ações penais ajuizadas com tal propósito pelo Ministério Público Federal entre os anos de 2012 e 2016. Ademais, a decisão tornou-se embaraçosa para o Estado na seara internacional, uma vez que a CIDH, em 2010, 
determinou que fosse afastada qualquer interpretação da Lei de Anistia que impedisse a punição dos responsáveis pelos crimes cometidos pelos agentes do Estado na região do Araguaia.

A simples transferência do poder das mãos dos militares para os civis não elimina a influência política dos militares sobre os centros de decisão. É preciso construir a rejeição da solução militar para resolver os problemas políticos. As sociedades democráticas devem construir Estados capazes de regular a autonomia das instituições militares. A responsabilidade pelos atos praticados pelos membros das instituições militares, ou por eventos provocados por elas, não pode ser alcançada sem que os demais pilares da autonomia militar sejam repensados e reorientados no seio da sociedade.

A arquitetura do poder construída ao longo do século XX no Brasil contempla o uso das armas enquanto instala ou desfaz governos democráticos. As soluções políticas não levam em conta os conflitos próprios da sociedade e, tampouco, o aprendizado com os erros. São as armas o recurso prontamente utilizado para gerir o poder quando o comportamento dos líderes ou do povo não satisfaz. As Forças Armadas são a instituição síntese da hierarquia absoluta a que todos deverão estar submetidos (TREVISAN, 1987, p. 72-73).

A autonomia das Forças Armadas é uma garantia para o desenvolvimento de suas atribuições e pode envolver três pilares. Primeiramente, a autonomia reside na liberdade para conduzir os assuntos internos à vida institucional; outro aspecto apresenta-se na livre possibilidade de articulação com outras instâncias constitucionalmente reconhecidas e, por fím, relaciona-se aos atos praticados por seus membros, por eventos provocados por ela e, ainda, por acontecimentos provocados por seus membros fora do âmbito institucional (OLIVEIRA et al., 1987, p. 12).

A autonomia das Forças Armadas vem sendo questionada na contemporaneidade, apontando-se a necessidade de controles civis sobre sua atuação. Verifica-se, amplamente, que a supressão do controle social sobre o poder político conduz o poder às mãos do corpo militar de forma permanente. As sociedades que escolhem conviver com o autoritarismo equilibram o poder através do uso da força, isto é, quando não for possí- 
vel conservar a dominação através de métodos políticos ou legais, o poder é restabelecido pelo uso da força. A política passa a exercer o poder de forma policialesca, voltada para a repressão interna (OLIVEIRA et al., 1987, p. 25).

No mesmo sentido, aponta-se a necessidade de rever a manutenção dos aparelhos militares, inclusive a justiça militar e a legislação correspondente, propondo-se a alteração do modelo vigente desde o tempo da ditadura militar, como condição para permitir a maturação e o aprofundamento da própria democracia. A percepção que a sociedade alimenta sobre os direitos individuais e os de minorias resta diminuída diante da conservação das estruturas legais e institucionais de uso da força do Estado (CABRAL, 2017, p. 98-99).

A concessão de anistia política no Brasil, especialmente durante o período republicano, embora comporte a análise de nuances específicas para a compreensão do seu sentido e do alcance de cada ato, segue uma tradicional perspectiva alicerçada nas regras de ouro que orientam a política nacional, a saber, a conciliação entre os grupos de poder e o uso de mecanismos democráticos como recurso para alcançar os propósitos das elites nacionais. As anistias políticas, portanto, desempenham duplo papel. Primeiramente, integram o conjunto de medidas que se destinam a manter as elites políticas no poder; por outro lado, realizam tal tarefa na condição de mecanismo que confere legitimidade democrática aos interesses almejados (LEMOS, 2002, p. 289 e 291).

Cada anistia política concedida em benefício de grupos civis e, simultaneamente, para militares ocupados da repressão contra os primeiros é expressão da compreensão solidamente utilizada pelos governantes no combate aos dissidentes políticos que agem tanto por meios violentos como por meio legítimos, tais como a greve ou mediante manifestação da liberdade de expressão. A restrição prevista na Constituição Federal de 1988, que estabeleceu a proibição de anistiar crimes de tortura e os considerados hediondos, entre outros, independentemente da presença de motivações políticas, encerra, formalmente, o arbítrio legislativo que autorizou inúmeras anistias políticas em benefício de integrantes das forças 
de segurança do país que cometeram graves violações de direitos humanos contra a população civil.

A elaboração do texto constitucional fez parte do projeto de transição política, na sua segunda fase, que viu despontar um regime democrático compreendido por muitos analistas, quanto ao aspecto político-institucional, como democracia vazia, pobre ou delegativa. A transição política quando se dá por ruptura alcança respostas institucionais mais amplas, uma vez que a cadeia do processo decisório sofre interrupção. O mesmo não se verifica quando a opção adotada é pela transição negociada. Nesse caso, preserva-se a governabilidade e a rotina do processo de decisão e reduz-se o espectro da mudança em curto prazo (MORAES, 2011, p. 140-141).

Os elementos políticos da transição iniciada na década de 1970 foram, portanto, recepcionados pelo ordenamento jurídico, que fundou a nova ordem, a qual se apresenta como cultura política fundada na versatilidade em criar formas jurídicas e institucionais no compasso da ordem internacional, avança como experimento político e que, no entanto, não deixa de ceder ao impulso de abandonar as escolhas formalmente consolidadas.

A atualidade das convicções firmadas ao tempo da abertura política pode ser percebida na análise da decisão do Supremo Tribunal Federal na Arguição de Descumprimento de Preceito Fundamental n. 153. A ordem constitucional inaugurada em 1988 não foi capaz de afastar por completo o propósito militar, tampouco a cultura política, nem mesmo as marcas deixadas pela aproximação entre o Poder Judiciário e os militares durante as ordens precedentes. Diante de tal conjuntura, a expectativa acerca da decisão na ADPF n. 320 não comporta maiores surpresas, embora possa haver mudança de orientação.

\section{Conclusão}

Fatores políticos interferem na produção e na interpretação das anistias políticas. A política nacional é construída a partir das regras da conciliação entre os interesses dos grupos de maior influência política; 
do continuísmo de maneirismos e de atores, independentemente do regime adotado; do uso dos instrumentos democráticos para viabilizar os objetivos acordados; do usual desprezo às regras políticas adotadas e do recurso ao uso das forças de segurança do Estado como meio para forçar o cumprimento dos propósitos traçados. As anistias políticas resultam de decisões construídas no curso do processo político desenvolvido segundo os critérios acima elencados.

A interpretação das anistias políticas realizadas pelo Poder Judiciário sofre as intercorrências do poder. Os membros da cúpula do Poder Judiciário travaram contato íntimo com os militares e seus valores sobretudo durante os governos ditatoriais. A interação resultou em modificações institucionais que repercutem após o advento da ordem constitucional de 1988. O Supremo Tribunal Federal ao interpretar o alcance das anistias políticas ao longo da experiência republicana construiu um certo posicionamento que a Constituição Federal de 1988 não logrou derrogar. Foram analisadas 15 decisões consideradas paradigmas que foram proferidas por este órgão sobre o tema.

Com base no universo pesquisado, conclui-se que o Supremo Tribunal Federal adotou a tese de que os efeitos de natureza penal e processuais penais das anistias políticas devem ser interpretados de forma ampla, não importando a condição política do beneficiário. Assim, apenas texto expresso na lei poderá afastar a incidência dos benefícios penais para determinados grupos. Por outro lado, deverão ser interpretadas restritivamente quanto às repercussões de caráter cível e administrativo, uma vez que esse tipo de previsão se constitui em elemento acidental para essa espécie normativa. Ademais, firmou o entendimento de que a interpretação das leis de anistia política deve dialogar com o momento histórico de sua produção. Fixou, também, a compreensão de que as revisões dos efeitos penais assegurados nas anistias concedidas competem ao Poder Legislativo. Quanto ao tema da conexão criminal, o Supremo Tribunal Federal adota a tese de que é possível ao legislador criar conexão especial para cada caso.

O Supremo Tribunal Federal ao decidir a Arguição de Descumprimento de Preceito Fundamental n. 153, de 2010, reiterou todos esses conceitos aplicáveis às anistias políticas na análise que realizou sobre a 
recepção da Lei n. 6.683, de 1979, pela ordem constitucional de 1988. Compreendeu-se que a Constituição Federal de 1988 se coaduna com a anistia concedida como parte do acordo traçado durante o processo de transição política que permitiu que o governo passasse das mãos dos militares para os civis na década de 1980. Na decisão, o órgão ratificou o seu posicionamento clássico sobre o tema, ressaltando os aspectos que são de maior relevo.

As anistias políticas, quando concedidas em benefício de grupos militares que cometeram crimes contra os opositores do regime político ingressam na condição de prerrogativa da instituição militar. Tal fenômeno verifica-se em virtude da destinação constitucionalmente atribuída aos militares no Brasil. As constituições republicanas atribuíram às Forças Armadas a condição de guardiões da Pátria, em caso de guerra externa, e da lei e da ordem no âmbito interno. Nesse último caso, quando os militares agem em defesa dos propósitos do governo, embora cometendo crimes, o legislador brasileiro costuma oferecer o benefício da anistia ao considerar presente a vinculação com os fatores do poder.

Tal orientação, contudo, passou a sofrer óbice constitucional. A Constituição Federal de 1988 limitou o campo de alcance das anistias, o que representou uma conquista democrática. O artigo $5^{\circ}$, XLIII, estabeleceu uma restrição ao instituto da anistia ao negar o arbítrio estatal para conceder o benefício para a prática do ato de tortura, o tráfico ilícito de entorpecentes e drogas afins, o terrorismo e os definidos como crime hediondo. Igualmente, definiu que respondem por tais delitos os mandantes, os executores e os que, podendo evitá-los, se omitirem.

O limite constitucional para a produção de anistias adotado no artigo $5^{\circ}$ aplica-se, também, às anistias políticas. No entanto, a escolha por tornar determinados tipos penais, considerados mais gravosos, insuscetíveis de anistia aplica-se, exclusivamente, para a produção normativa posterior a 1988. Os atos de anistia política concedidos no ato de convocação da Assembleia Constituinte, de 1985, e no Ato das Disposições Constitucionais Transitórias, ADCT, publicado em conjunto com a promulgação do texto constitucional, em 1988, não se sujeita a essa limitação. 
A influência hodierna do militarismo sobre a política nacional e, especificamente, sobre o Poder Judiciário revelou-se na decisão da referida ADPF n. 153. A ordem democrática inaugurada em 1988 não modificou a destinação das instituições militares o que lhes garante certas prerrogativas, inclusive a anistia concedida através da Lei n. 6.683, de 1979, que alcança agentes castrenses que cometeram graves crimes nos combates desenvolvidos contra os dissidentes políticos. Tal atitude contrasta com o repúdio à prática de tortura inserido no texto constitucional e com a obrigação internacional advinda da sentença proferida pela Corte Interamericana de Direitos Humanos que condenou o Estado brasileiro a afastar qualquer interpretação da anistia de 1979 que impedisse a persecução penal contra os agentes do Estado que cometeram crimes em combates travados durante a Guerrilha do Araguaia.

\section{Referências}

BRASIL. Supremo Tribunal Federal. Arguição de Descumprimento de Preceito Fundamental n. 153. Conselho Federal da Ordem dos Advogados do Brasil. Relator: Eros Grau. Brasília, DF, 29 de abril de 2010. Disponível em: http://redir.stf.jus.br/paginadorpub/paginador. jsp?docTP=AC\&docID=612960. Acesso em: 10 jul. 2018.

BRASIL. Supremo Tribunal Federal. Habeas Corpus n. 1.386.

Francisco de Paula Azevedo e Sousa. Relator: Piza e Almeida. Rio de Janeiro, RJ, 4 de julho de 1900.

BRASIL. Supremo Tribunal Federal. Habeas Corpus n. 29.151. Eduard Arnold. Relator: Laudo de Camargo. Rio de Janeiro, DF, 26 de setembro de 1945. Disponível em: http://redir.stf.jus.br/paginadorpub/paginador. jsp?docTP=AC\&docID=579332. Acesso em: 18 fev. 2018.

BRASIL. Supremo Tribunal Federal. Habeas Corpus n. 34.866. Antonio Pan Fidalgo; Oscar Pietro e Benedito Terezo. Relator: Luiz Gallotti. Rio de Janeiro, DF, 3 de abril de 1957. 
BRASIL. Supremo Tribunal Federal. Informativo n. 627, 2011.

Disponível em: http://www.stf.jus.br/arquivo/informativo/documento/ informativo627.htm. Acesso em: 20 maio 2017.

BRASIL. Supremo Tribunal Federal. Notícias, 2012. Disponível em: http://www.stf.jus.br/portal/cms/verNoticiaDetalhe. asp?idConteudo=218387. Acesso em: 21 maio 2017.

BRASIL. Supremo Tribunal Federal. Notícias, 2009. Disponível em: http://www.stf.jus.br/portal/cms/verNoticiaDetalhe. asp?idConteudo=111608. Acesso em: 21 maio 2017.

BRASIL. Supremo Tribunal Federal. Recurso Criminal n. 1.019. Justiça Pública. Gastão Dias Velloso e outros. Relator: Ary Franco. Rio de Janeiro, DF, 5 de agosto de 1957.

BRASIL. Supremo Tribunal Federal. Recurso Criminal n. 1.025. Justiça Pública. Relator: Hahnemann Guimarães. Rio de Janeiro, DF, 28 de abril de 1958.

BRASIL. Supremo Tribunal Federal. Recurso Criminal n 1.400. Altino Rodrigues Dantas Júnior; Paulo Esper Pimenta e outra. Ministério Público Militar. Relator: Leitão de Abreu. Brasília, DF, 14 de setembro de 1979a.

BRASIL. Supremo Tribunal Federal. Recurso Criminal n. 1.396. Maria Aparecida dos Santos e outros. Ministério Público Militar. Relator: Xavier de Albuquerque. Brasília, DF, 18 de setembro de 1979b.

BRASIL. Supremo Tribunal Federal. Recurso Criminal n. 1.401. Jeffersson Santos do Nascimento. Ministério Público Militar. Relator: Cordeiro Guerra. Brasília, DF, 21 de setembro de 1979c.

BRASIL. Supremo Tribunal Federal. Recurso Criminal n. 1.410.

Gilberto Telmo Sidney Marques; José Bento da Silva e Carlos Thomoshenko Soares de Sales. Ministério Público Militar. Relator: Decio Miranda. Brasília, DF, 5 de outubro de 1979d.

BRASIL. Supremo Tribunal Federal. Recurso de Habeas Corpus n. 28.294. José Maria Neves Sobrinho. Relator: Philadelpho de Azevedo. Rio de Janeiro, DF, 14 de outubro de 1942. Disponível em: http://redir. 
stf.jus.br/paginadorpub/paginador.jsp?docTP=AC\&docID $=573363$. Acesso em: 20 fev. 2018.

BRASIL. Supremo Tribunal Federal. Recurso de Habeas Corpus n. 59.834. Carlos Eugênio Sarmento Coelho da Paz. Superior Tribunal Militar. Relator: Firmino Paz. Brasília, DF, 04 de maio de 1982.

BRASIL. Supremo Tribunal Federal. Recurso Extraordinário n. 125.641. União Federal. Manoel Teixeira. Relator: Celso de Mello. Brasília, DF, 12 de março de 1991.

BRASIL. Supremo Tribunal Federal. Recurso Extraordinário Criminal n. 10.177. Procurador Geral do Estado do Estado de Pernambuco. Tribunal de Apelação. Relator: Orosimbo Nonato. Rio de Janeiro, DF, 11 de maio de 1948a. Disponível em: http://redir.stf.jus.br/paginadorpub/ paginador.jsp?docTP=AC\&docID=597856. Acesso em: 20 fev. 2018.

BRASIL. Supremo Tribunal Federal. Recurso Extraordinário Criminal n. 10.998. Procurador Geral do Estado do Estado de Pernambuco. Tribunal de Justiça de Pernambuco. Relator: Barros Barreto. Rio de Janeiro, DF, 7 de junho de 1948b. Disponível em: http://redir.stf.jus.br/ paginadorpub/paginador.jsp?docTP=AC\&docID=596676. Acesso em: 20 fev. 2018.

CABRAL, Rafael Lamera Giesta. Reforma das instituições para a democracia e o legado autoritário: a branda justiça de transição no Brasil. Revista de Direitos Fundamentais \& Democracia, Curitiba, v. 22, n. 3, p. 84-108, set./dez., de 2017.

D’ARAÚJO, Maria Celina; CASTRO, Celso. Militares e política na nova república. Rio de Janeiro: FGV, 2001.

LEMOS, Renato. Anistia e crise política no Brasil pós-1964. Revista Topoi, Rio de Janeiro, p. 287-313, dez. 2002.

MÉNDEZ, Juan E. Responsabilização por abusos do passado. In: REÁTEGUI, Félix (coord.). Justiça de transição: manual para a América Latina. Brasília: Comissão de Anistia, Ministério da Justiça; Nova Iorque: Centro Internacional para a Justiça de Transição, 2011. p. 193-225. 
MORAES, Filomeno. Constituição econômica brasileira: história e política. Curitiba: Juruá, 2011.

NUNES, Castro. Teoria e prática do Poder Judiciário. Rio de Janeiro: Edição Revista Forense, 1943. Disponível em: http://www.stf.jus.br/ bibliotecadigital/DominioPublico/6969/pdf/6969.pdf. Acesso em: 11 nov. 2017.

OLIVEIRA, Eliézer Rizzo de; CAVAGNARI FILHO, Geraldo L.; MORAES, João Quartim de; DREIFUSS, René Armand. As Forças Armadas no Brasil. Rio de Janeiro: Espaço e Tempo, 1987.

PEREIRA, Anthony W. Ditadura e repressão. O autoritarismo e o estado de direito no Brasil, no Chile e na Argentina. Trad. Patrícia de Queiroz Carvalho Zimbres. São Paulo: Paz e Terra, 2010.

SERBIN, Kenneth P. Diálogos na sombra: bispos e militares, tortura e justiça social na ditadura. Trad. Carlos Eduardo Lins da Silva. São Paulo: Companhia das Letras, 2001.

STEPAN, Alfred. Os militares na política. As mudanças de padrões na vida brasileira. Trad. Ítalo Tronca. Rio de Janeiro: Artenova, 1975. TREVISAN, Leonardo. O que todo cidadão precisa saber sobre instituição militar e Estado brasileiro. São Paulo: Global, 1987. ZAVERUCHA, Jorge. Frágil democracia: Collor, Itamar, FHC e os militares (1990-1998). Rio de Janeiro: Civilização Brasileira, 2000.

Rosangela Souza Bernardo é Professora do Curso de Direito da Faculdade Princesa do Oeste, Crateús, Ceará. Mestra em Direito Constitucional pela Universidade de Fortaleza. Especialista em Direito Constitucional e Direito Processual Constitucional pela Universidade Estadual do Ceará; integra o Grupo de Pesquisa "Estado, Política e Constituição" (CNPq/UNIFOR).

E-mail: rosangela.bernardo@gmail.com; rosangelabernardo@fpocrateus.com.br Endereço profissional: Rua Zacarias Carlos de Melo, São Vicente, Cratéus, CE. CEP: 63700-000. 
Filomeno Moraes é Professor titular do Programa de Pós-Graduação em Direito Constitucional/Mestrado e Doutorado da Universidade de Fortaleza. Doutor em Direito pela Universidade de São Paulo. Livre-docente em Ciência Política pela Universidade Estadual do Ceará. Mestre em Ciência Política pelo Instituto Universitário de Pesquisas do Rio de Janeiro; líder do Grupo de Pesquisa "Estado, Política e Constituição" (CNPq/UNIFOR).

E-mail: filomenomoraes@uol.com.br; filomeno@unifor.br

Endereço profissional: Rua Washington Soares, n. 1.321, Edson Queiroz, Fortaleza, CE. CEP: 60811-905. 